\title{
Tverrfaglig samarbeid ivaretar hjemmeboende multisyke pasienter bedre
}

En ny måte å organisere helsetjenestene på i Smøla kommune har ført til bedre samarbeid mellom ulike yrkesgrupper. Det kommer pasientene til gode.

Trude Fløystad Eines

Førsteamanuensis

Høgskolen i Molde

Jorunn Hoås Rødal

Forskningsassistent

Møreforskning, Molde

Maria Sandsmark

Forsker II

Møreforskning, Molde

Cecilie Katrine Utheim Grønvik

Høgskolelektor

Høgskolen i Molde, Vitenskapelig høgskole i logistikk

\begin{tabular}{|l|l|l|l|l|l|l|l|l|l|l}
\hline Arbeidsmiljø & Behandling & Brukermedvirkning & Forebging \\
\hline
\end{tabular} 
Systematisk tverrprofesjonelt samarbeid om hvordan risikopasienter følges opp og vurderes, synes å være en smart måte å organisere hjemmebaserte tjenester på. I Smøla kommune kaller de dette en virtuell avdeling. Virtuell avdeling er ingen fysisk avdeling, men et rammeverk hvor all relevant informasjon om pasienten underlegges en tverrprofesjonell vurdering i tett samarbeid med pasient og pårørende.

De ansatte i helse- og omsorgstjenestene jobber under kontinuerlig press for å løse utfordringene med en voksende gruppe eldre med mer komplekse sykdomsbilder, $\mathrm{i}$ kombinasjon med strammere kommuneøkonomi. Kommunene må derfor utvikle stadig nye og smartere måter å arbeide og samhandle på. I tillegg viser stortingsmeldingene «Morgendagens omsorg» (1) og «Innovasjon i omsorg» (2) at det er en klar forventning om at pasientens medvirkning skal styrkes i helse- og omsorgstjenestene.

\section{Ny måte å organisere på}

Med inspirasjon fra England har Smøla kommune med sine cirka 2000 innbyggere innført en ny måte å organisere helsetjenestene på, som kalles «virtuell avdeling». Virtuell avdeling (VA) er ingen fysisk avdeling, men et rammeverk hvor all relevant informasjon om pasienten underlegges en tverrprofesjonell vurdering i tett samarbeid med pasient og pårørende $(3,4)$. Slik legges det til rette for mer behovsdrevne løsninger og økt pasientinvolvering.

I tillegg vektlegges bruk av systematiske kartleggingsverktøy som NEWS (National early warning score) (5) og SKUV (systematisk klinisk unders $\varnothing$ kelse og vurdering) (6) for å få en helhetlig oversikt over pasientenes behov - og ulike risikovurderinger.

I prosjektet «Virtuell avdeling i kommunehelsetjenesten: Smartere og bedre samhandling for multisyke eldre», har vi innhentet informasjon om ansattes erfaringer med VA og belyst hvilke samfunns $\varnothing$ konomiske effekter ordningen bidrar til (7). 


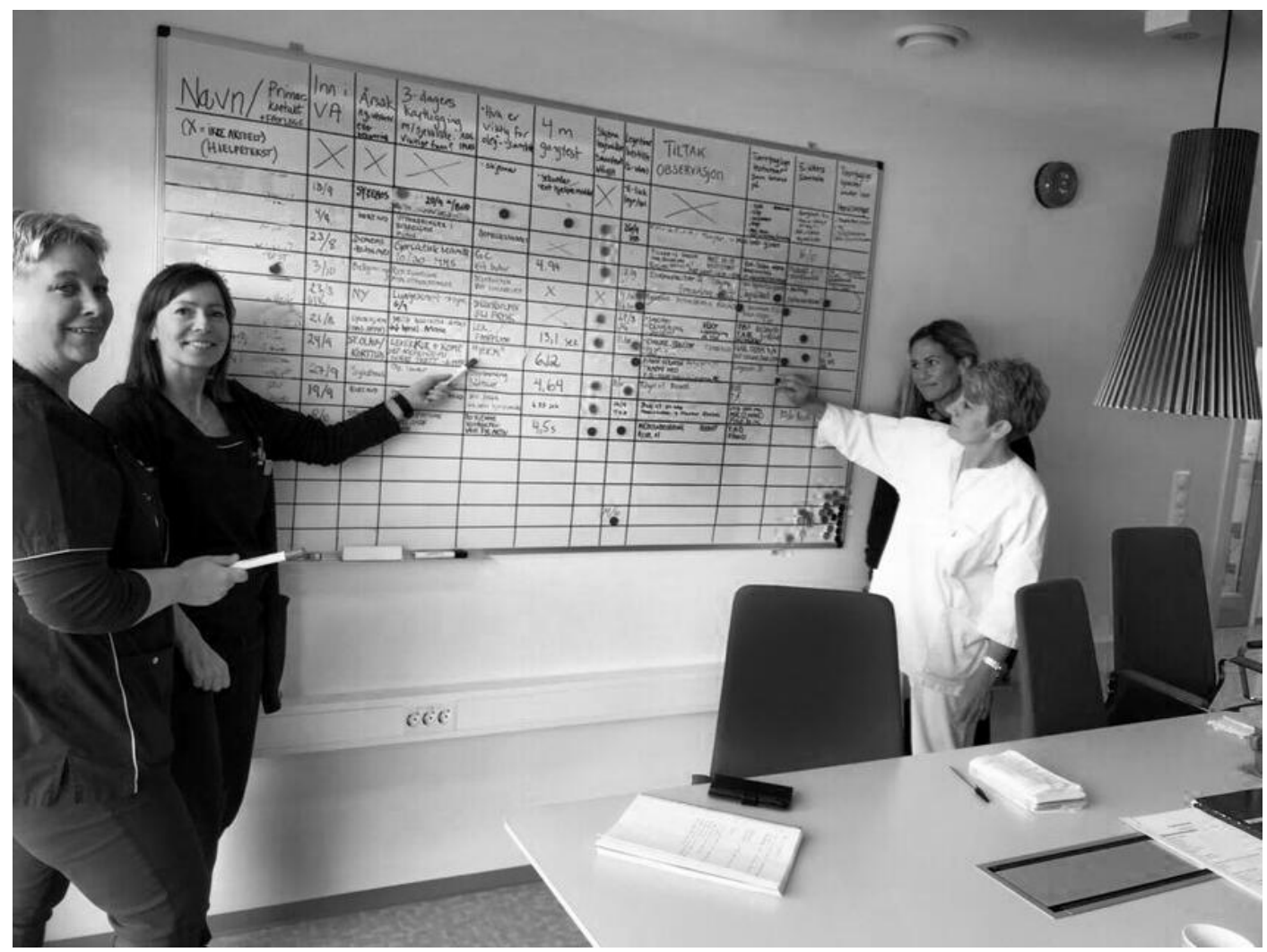

TAVLEMØTE: Det tverrprofesjonelle teamet planlegger oppfølging av pasienter på et tavlemøte. Fra venstre: teamleder Bodil Fagerheim, teamleder Cicilie Sørstrand, fysioterapeut Kari Lie og leder den virtuelle avdelingen i Smøla kommune Gunvor Folde. Foto: Inger-Lise Lervik

\section{Slik jobber teamet}

Smøla kommune har jobbet strategisk med å implementere ulike statlige satsingsområder for $\varnothing \mathrm{kt}$ pasientsikkerhet og kvalitetssikring i helsetjenestene over flere år. Prosjektet «Virtuell avdeling for multisyke eldre» ble igangsatt i mars 2018, og etter et år har 65 pasienter vært innom avdelingen.

Pasientene følges opp av kommunens tverrprofesjonelle team som består av tre kommuneleger, to-tre sykepleiere, fysioterapeut, ergoterapeut og en klinisk sosionom. Teamet ledes av en spesialsykepleier med master i avansert klinisk sykepleie. De møtes minst én gang i uken for å vurdere status og videre oppfølging av hver pasient som er innlagt.

\section{三 «De møtes minst én gang i uken for å vurdere status og videre oppfølging av hver pasient som er innlagt. »}

Den tverrprofesjonelle organiseringen i VA gir et rammeverk for vurdering og levering av hjemmebaserte tjenester til et prioritert utvalg av pasienter med forhøyet risiko for å bli (re-)innlagt på sykehus eller sykehjem. 
Pasientene består i hovedsak av personer som har utfordringer knyttet til akutt forverring av sykdom, skader og/eller funksjonssvikt. De fleste av pasientene som har vært innlagt i VA så langt, har hatt behov for tett og tverrprofesjonell oppfølging etter utskrivelse fra institusjon eller for å unngå innleggelser i sykehjem eller sykehus.

Inneliggende pasienter i VA får en systematisk og tverrprofesjonell oppfølging i fire til fem uker. Deretter gjennomføres en evaluering, hvor det tverrprofesjonelle teamet vurderer om målene for perioden er nådd. I tett samarbeid med pasient og pårørende utarbeides en plan for oppfølging etter utskrivelse.

\section{Ansattes erfaringer}

For å få kunnskap om de ansattes opplevelse av å arbeide med VA, gjennomførte vi et fokusgruppeintervju. Seks av de ansatte i VA-teamet samtykket til å delta.

Fokusgruppeintervjuet tok utgangspunkt i deres erfaringer med tverrprofesjonell samhandling i VA, samt utfordringer og gevinster.

\section{三 «Informantene ga uttrykk for at tverrprofesjonelt samarbeid er viktig for å ivareta det økende antallet multisyke pasienter.»}

Informantene ga uttrykk for at tverrprofesjonelt samarbeid er viktig for å ivareta det $\varnothing$ kende antallet multisyke pasienter med komplekse utfordringer. Ved å jobbe tverrprofesjonelt, utveksler de ansatte kunnskap og informasjon, som bidrar til bedre løsninger med utgangspunkt i pasientenes behov og $\varnothing$ nsker. I tillegg fant vi at arbeidsformen i VA har stor betydning for $\varnothing \mathrm{kt}$ pasientsikkerhet og kvalitet på tjenestene de leverer.

\section{Flere gevinster}

Innføring av VA har bidratt til en bedre avklaring av de ulike profesjonenes roller og ansvar. Informantene fortalte at dette har bidratt til $\varnothing \mathrm{kt}$ jobbmotivasjon og trivsel. Det tverrprofesjonelle samarbeidet i VA har gitt st $\varnothing$ rre gjensidig anerkjennelse av kompetanse, og de ulike profesjonene kontakter hverandre oftere for å utveksle erfaring også utenom VA-møtene. 
Andre gevinster ved tverrprofesjonelt samarbeid, er $\varnothing \mathrm{kt}$ kunnskap og bevissthet som reduserer misforståelser og gir mer effektiv bruk av tid og ressurser. Flere opplevde at VA har bidratt til reduksjon i innleggelser og reinnleggelser i sykehus og sykehjem, fordi akutt forverring er blitt avdekket på et tidligere tidspunkt.

Informantene nevnte at de systematiske vurderingene og oppfølgingene har ført til at behandling blir igangsatt raskere og pasienter i større grad blir behandlet i hjemmet. I tillegg mente de at etableringen av VA har ført til at færre pasienter blir liggende ferdigbehandlet på sykehuset.

Enhver endring medfører ofte $\varnothing \mathrm{kt}$ arbeidsbelastning i en periode, noe også funnene i denne studien viser. De ansattes opplevelse av å levere tjenester av høy kvalitet gjennom tett og konstruktivt tverrprofesjonelt samarbeid i VA, synes imidlertid å overskygge merarbeid i etableringsfasen i det første driftsåret.

For å utvikle VA-konseptet, mente informantene at det er behov for $\varnothing \mathrm{kt}$ interkommunalt samarbeid som en mulig løsning for å skaffe kompetanse de ikke har tilgang på i dag, for eksempel ernæringsfysiolog og psykolog.

\section{Konklusjon}

Innføring av virtuell avdeling i Smøla kommune har bidratt til $\emptyset \mathrm{kt}$ systematisk tverrprofesjonell samhandling i ivaretakelse av multisyke pasienter i hjemmetjenesten.

Felles fokus på viktigheten av å levere pasient- og behovsdrevne helsetjenester, bidrar til bedre forebyggende og behandlende tiltak for å redusere alvorlig forverring av kronisk sykdom. I tillegg kan tidlig oppdagelse av akutt forverring som for eksempel infeksjoner, bidra til raskere behandling. Dette sparer både pasienter og samfunnet for kostbare innleggelser og reinnleggelser i sykehjem eller sykehus.

\section{三 «Dette sparer både pasienter og samfunnet for kostbare innleggelser og reinnleggelser i sykehjem eller sykehus.»}


Gjennom mer systematisk jobbing, effektiv tidsbruk og redusert sykefravær på grunn av økt trivsel på jobb, kan kommunen i tillegg spare utgifter. Dette kan på lang sikt redusere behovet for nye sykehjemsplasser. I tillegg kan det å yte tjenester av god kvalitet $\varnothing$ ke pasientsikkerheten.

Vi mener derfor at andre kommuner har mye å lære av den systematiske teambaserte tverrprofesjonelle samhandlingen Smøla kommune har i sin virtuelle avdeling.

\section{Referanser}

1. Norges offentlige utredninger: NOU 2011: 11. Innovasjon i omsorg. Oslo: Departementenes servicesenter, Informasjonsforvaltning; 2011.

2. Meld. St. nr. 29 (2012-2013). Morgendagens omsorg. Oslo: Helse- og omsorgsdepartementet; 2013.

3. Jones J, Carroll A. Hospital admission avoidance through the introduction of a virtual ward. British Journal of Community Nursing. 2014;16(7):330-34. DOI:

$\underline{10.12968 / \text { bjen.2014.19.7.330 }}$

4. Lewis G, Moore Z, Doyle F, Martin A, Nugent LE. A community virtual ward model to support older persons with complex health care and social needs. Clinical Interventions of Aging. 2017; 12:985-93. DOI: 10.2147/CIA.S130876

5. Royal College of Physician. National early warning score (NEWS) 2. Tilgjengelig fra:

https://www.rcplondon.ac.uk/projects/outputs/national-earlywarning-score-news-2 (nedlastet 08.10.2019).

6. Brevik S, Tymi A. Hva innebærer systematisk klinisk unders $\varnothing$ kelse i sykepleie? Sykepleien Forskning 2013;8(4):32432.

7. Eines TF, Grønvik CKU, Rødal JH, Sandsmark M. Virtuell avdeling i kommunehelsetjenesten: Smartere og bedre samhandling for multisyke eldre. Arbeidsrapport. Molde: Møreforsking AS; 2019. Tilgjengelig fra: http://www.moreforsk.no/publikasjoner/rapporter/samfunn/vi rtuell-avdeling-i-smola-kommune--smartere-og-bedresamhandling-for-hjemmeboende-multisyke-eldre/1075/3306/ (nedlastet 08.10.2019). 